\title{
Tanssi, teatteri ja taiteen johtaminen
}

Erika Sauer, Perttu Salovaara, Anne-Maria Mikkonen \& Arja Ropo (2010).

Johtajuuden uusi taide. Tampere University Press. 146 s. ISBN: 978-951-44-8173-4

JOHTAMISEN tarkasteluun on monia eri tulokulmia. Uuden perspektiivin keksiminen ei ole ongelma, mutta sen käyttäminen johtamisen jäsentämiseen helposti on sitä. Lopputuloksena tulisi olla uusi, mutta ymmärrettävä kuva johtamisesta, joka mahdollisesti jäsentyy keskinäissuhteissaan oudosti, mutta myös kiinnostavasti.

Erika Sauer, Perttu Salovaara, Anne-Maria Mikkonen ja Arja Ropo vievät johtajuutta eteenpäin eri taidemuotojen tarjoamien näkökulmien kautta. Heidän mukaansa rationaalinen tieto johtamisesta sulkee sisäänsä joitakin johtamisen puolia, mutta ei kykene tavoittamaan sitä kokonaisuudessaan. Ihmisten johtamiseen liittyvä tieto muodostuu tunteiden, kehollisten kokemusten ja erilaisten kontaktien kautta. Johtaja, joka uskaltaa avautua taiteen monimuotoisuudelle, voi laajentaa näkemystään, rikastaa kaunopuheisuuttaan ja ammentaa kokemuksistaan pintaa syvemmältä.

Teos lähtee liikkeelle kuvataiteesta ja katseella johtamisesta. Siinä sivussa annetaan väärä todistus historiasta väittämällä, että Fred[e]ri[c]k Taylor, taylorismin ja massatuotannon isä, olisi pitänyt johtamisen nyrkkisääntönä sitä, että yksi työnjohtaja saattoi valvoa kerrallaan enintään 12 työ- miestä ja että perinteisten taylorismin mallien mukaan rakennettujen tehtaiden katonrajassa oli työnjohdon koppi, josta näki koko tehdasalueen. Tämä herättää huomioimaan eron taiteen ja tieteen välillä. Tämä on taiteellinen teos. Asialla - tuntemus valvovan katseen alla toimimisesta - on kuitenkin merkitystä. Jotkut ottavat katseen omakseen ja tarkastavat onko kaikki kunnossa. Toisille katse on valokeila, jota he ovat odottaneet ja jossa on heidän tilaisuutensa loistaa. Kolmansille se merkitsee jatkuvuutta ja turvallisuutta. Katse voi olla kaikissa tapauksissa sama.

Kuten tekijät kirjoittavat, katse, pelkkä katseen mahdollisuuskin, koskettaa ja tuo kosketus voi olla niin vapauttava kuin vapautta rajaava. Taiteellista vapautta on myös väitteessä, että Nietzsche tarkoittaisi "vallantahdolla"("will to power") sitä, että kaikki teot, sanat tms. ovat aina subjektiivisesti valittuja ja johdattavat näin subjektiivisesti valittuihin otteisiin todellisuudesta, eivät totuuteen. Tämä on lähempänä Nietzschen perspektivismin ideaa. Voi myös kysyä tekijöiden tapaa käyttää Mary Parker Follet $[\mathrm{t}]$ in erottelua power over/ power with tavalla, joka tarkoittaa sekä kanssa-johtamista että valtaa toisen kanssa - eikö johtamisen ja vallankäytön välillä olisi hyvä nähdä jonkinlainen ero?

"Taylor", "Nietzsche" ja "Follett" ovatkin läsnä taiteellisen vaikutelman ja akateemisen tekstiestetiikan vaatimuksesta, eivät totuuden tavoittelun vuoksi. Se, että hankalasti hahmotettavia asioita, kuten johtaminen, voi ja usein kannattaa lähestyä muiden ilmaisumuotojen keinoin, tulee kuitenkin tekstissä esille ja puhuu tekijöiden tarkoituksen puolesta. Lopputulos on hahmotelma tai luonnostelma aiheesta, ajatuksen aihio. Tällaisena se on omiaan kuitenkin herättämään ajatuksia ja rohkaisee jatkamaan ajatuksen kehittelyä.

Teatteri taidemuotona perustuu sopimuksiin rooleista niin näyttämöllä kuin esittäjien ja yleisön välillä. Elämämme on roolitettua ja elämme roolien kautta. Teatterista tutut draama, tragedia, lavastus, tehokeinot, tunteiden ja motiivien näyttäminen jne. tarjoavat välineitä käsitellä toimintaa toimijoita suojaavalla tavalla. Kun itselle nauraminen onnistuu aidosti vain harvoilta, oman roolin tarkastelu ja ironisointi luontuu useammalta. Johtamisen käytännössä laaja tunnerepertuaari voi olla yhtä merkittävä kuin laaja muuntautumiskyky näyttämötyössä. Kyky tavoittaa toisen ihmi- 
sen tilanne ja kokemusmaailma, toisen ymmärtäminen, on johtamisessa voimavara. Miten teen näkymättömän itsessäni näkyväksi toisille ja kuinka kykenen tavoittamaan omassa kokemuksessa sen, mikä toisessa jää näkyvän taakse. Teksti vain on siinä määrin kiinni teatterin maailmassa, että sen anti varsinaisen teeman, johtajuuden taiteen, kannalta jää sangen ohueksi.

Johtajuuden tanssi -luvussa nousevat esille aistit, tunteet ja ajattelun yhdistävä kehollisuus, liikkeen yhteensovittaminen, vastavuoroisuus ja esityksen yhteinen työstäminen. Tanssissa liike kysyy ja liike vastaa kysymykseen. Jännitteet rakentavat kokonaisuutta ja vievät sitä eteenpäin. Tuloksena on parhaimmillaan kollektiivista luovuutta ja yhteistä yltämistä korkeammalle. Osallistujat tuovat kokonaisuuteen oman panoksensa ja saavat itselleen kokonaisuudesta. He ruokkivat yhteistä paloa, ovat siitä yhteisvastuullisia, ja saavat energiansa sen lämmöstä. Liittyminen ei edellytä hengenheimolaisuutta vaan riittää, että tavoittaa rytmin, liikkeen, energian ja tunnelman. Tässä luvussa käsitellään valtaa, defensiivistä kommunikaatiota, dialogin tasoja, mutta samalla etäännytään tanssista. Käsittely kuihtuu kokoon tai, näkökulmasta riippuen, laajenee tavalla, jonka lienee ominainen konsultaatiolle yritysperformanssina. Teksti kuulostaa täydeltä, vaikka tosiasiassa kuulijan korvissa kumisee lähinnä sanojen tyhjyys. Se viihdearvo, joka sisältyy sujuvaan esittämi- seen ja jolla mitäänsanomattomuus peitetään, ei välity tekstistä. Tarkastelulle olisi ehkä ollut hyödyksi jonkinlainen minimalismi tietoisena pyrkimyksenä vähempään, jonka kautta sitten olisi pyritty näyttämään maksimaalisen paljon. Esitys ei tässä vain toimi.

Viimeinen varsinainen luku ei puhu musiikkitaiteesta vaan kuuntelu- ja musiikkimetaforasta. Teksti soljuu sujuvasti ja valottaa orkesterisoittajan arkea. On kiinnostavaa lukea, että orkesterin johtajan on osattava soittaa jotakin muutakin instrumenttia kuin orkesteria itseään. Konsertti on kaikkien, myös yleisön, yhteinen ponnistus. Improvisointi ja muuntelu, joka on jazz-musiikissa henki ja elämä, istuu konserttimusiikin kokonaisuuteen huonosti. Rockmusiikki, bändäys ja brändäys kappaleet alleviivaavat edelleen kirjoittajan teknistä taitavuutta tekstin tuottajana. Teksti toimii mainiosti johtajana ja vie lukijaa kuin naru pässiä kohti huomiota, että johtamisen reivit ovat sysäämässä syrjään johtamisen valssin. Tekijät kokoavat tarkoituksensa seuraavasti: "Olemme halunneet tuoda esiin miten eri taidemuodot avaavat johtamiseen epätäydellisyyden ja ristiriitaisuuden näkökulman. Tätä ei pidä ymmärtää lisämausteena erilaisiin johtamisoppeihin, vaan kokonaan toisena tapana ajatella johtamisesta ja johdettavana olemisesta." (s. 141.)

Loppuluvun aluksi tekijät toteavat teoksensa luonnehtivan yhtä kehitysvaihetta ajattelussaan. Kehitysvaiheen saattamisessa jul- kaisukelpoiseksi on jotakin samaa kuin siinä, että teatterit ja vastaavat päästävät katsojat seuraamaan harjoituksia. Harjoituksia ei voi arvioida samoilla kriteereillä kuin valmiiksi tarkoitettua esitystä eikä niitä mennä seuraamaan samasta syystä. Se, mitä harjoitellaan, miten harjoituksia johdetaan, miten esityksen osat muotoutuvat, ilmaisu täsmentyy, liikekieli löytyy jne. on monella tavalla kiinnostavaa, mutta se harvemmin jalostaa katsojaa samalla tavalla kuin kokonainen teos tai esitys. Tämä ajattelun kehitysvaiheen kuvaus on joukko oteharjoituksia ja improvisaation kaltaista liikkumista taiteen tekemisen, johtamisen tietämisen ja konsultointityön harjoittamisen areenoilla ja niiden välillä. Takakannen teksti toteaa, että kysymyksessä on ensimmäinen suomenkielinen esitys johtamisen, luovuuden ja taiteen liittymäkohdista.

Vaikka esitys ei näyttäydykään hyvin harkittuna ja onnistuneena, tuo se kuitenkin esille monia tärkeitä ja tuoreita näkökohtia liittyen taiteeseen, johtamiseen ja luovuuteen. Tekijöistä sanotaankin takakannessa, että he pyrkivät esteettisen, kehollisen johtamisosaamisen kehittämiseen. Tavoitteessa ei ole mitään vikaa - sitä kohden pitää vain pyrkiä nykyistä ankarammin.

Vesa Huotari erikoistutkija Poliisiammattikorkeakoulu 